\title{
Superficial dye penetration of two conventional ionomers used as dental fissures sealants
}

\begin{abstract}
- Marcella C. B. Malta Department of Community and Preventive Dentistry, School of Dentistry of the State University of Rio de Janeiro (FOUERJ), Rio de Janeiro, RJ, Brazil • Márcia R. T. C. Andrade Department of Pediatric Dentistry, School of Dentistry, Health Institute of the Federal University Fluminense (UFF), Nova Friburgo, RJ, Brazi - Mirian de W. S. de Marsillac Department of Community and Preventive Dentistry, School of Dentistry of the State University of Rio de Janeiro (FOUERJ), Rio de Janeiro, RJ, Brazil • Luiz H. M. Prates Department of Stomatology, Dental School of the Federal University of Santa Catarina (UFSC), Florianópolis, SC, Brazil • Ricardo de S. Vieira Department of Stomatology, Dental School of the Federal University of Santa Catarina (UFSC), Florianópolis, SC, Brazi
\end{abstract}

ABSTRACT || Objective: This study aimed to evaluate surface dye penetration of two conventional glass ionomer cements (GIC), one of them a high viscous ionomer. Methods: 20 standard disk samples measuring $2 \mathrm{~mm}$ thick and $4 \mathrm{~mm}$ in diameter were made for each conventional GIC. The high viscous ionomer was used as the control (Group 1). Samples were embedded in wax and submitted to $\mathrm{pH}$ cycling for 7 days simulating a high cariogenic challengein a kiln $\left(37^{\circ} \mathrm{C}\right)$. All samples were brushed with an extra-soft bristles infant toothbrush to mimic oral hygiene after exposure to a demineralizing solution for 6 hours. The samples were immersed in a $1 \%$ methylene blue solution for 2 hours at the end of cycling. The Mann-Whitney Rank Sum Test was used to analyze the difference between the two GIC. Results: All samples disclosed a superficial dye penetration of 0.6 to $1.5 \mathrm{~mm}$ depth. There was no statistical difference between the GIC tested $(\mathrm{p}=0.883)$. Conclusion: Both GIC tested in this study exhibited superficial dye penetration to depths of at least until their superficial third.

DESCRIPTORS | Glass Ionomer Cements; Pit and Fissure Sealants; Materials Testing.

RESUMO | Penetração de corante superficial de dois ionômeros convencionais usados como selantes de fissuras dentárias • Objetivo: Este estudo in vitro objetivou avaliar a infiltração superficial de dois cimentos de ionômero de vidro (CIV) convencionais, sendo um de alta viscosidade. Método: 20 amostras de discos padronizados de CIV, com $2 \mathrm{~mm}$ de espessura e $4 \mathrm{~mm}$ de diâmetro, foram feitos para cada grupo. O CIV de alta viscosidade foi utilizado como controle (Grupo 1). Esses corpos de prova foram embutidos em blocos de cera e submetidos à ciclagem de $\mathrm{pH}$ por 7 dias, a fim de simular um alto desafio cariogênico em estufa à $37^{\circ} \mathrm{C}$. Todas as amostras foram escovadas com uma escova de dentes infantil de cerdas extra macias para reproduzir a higiene bucal após a exposição por 6 horas a solução desmineralizante. Ao final do processo de ciclagem de pH os corpos de prova foram submersos em azul de metileno à $1 \%$ por 2 horas. $O$ teste estatístico Mann-Whitney foi usado para avaliar a diferença entre os dois CIV. Resultados: Todas as amostras tiveram mais de 0,5 mm de infiltração superficial. Não ocorreu diferença estatística significante entre os CIV testados $(p=0,883$ ). Conclusão: Ambos CIV testados no presente estudo apresentaram infiltração superficial de corante na profundidade de até pelo menos um terço a partir da sua superfície.

DESCRITORES | Cimentos de Ionômeros de Vidro; Selantes de Fossas e Fissuras; Teste de Materiais.

CORRESPONDING AUTHOR | Mirian de Waele Souchois de Marsillac School of Dentistry, State University of Rio de Janeiro • Boulevard 28 de Setembro, 157, sala 226 Rio de Janeiro, RJ, Brazil • 20551-030 E-mail: mwsm36@gmail.com

- Received Jan 21,2021 • Accepted Apr. 5, 2021

• Dol: http://dx.doi.org/10.11606/issn.2357-8041.clrd.2021.181208 


\section{INTRODUCTION}

Atraumatic restorative treatment (ART) is a technique that provides restoration of cavities and seals adjacent pits and fissures, combining preventive and restorative procedures. ${ }^{1}$

Moderate-quality evidence for using resin-based sealants compared with no sealant in children's permanent molars was found in a systematic review with meta-analysis. ${ }^{2}$ The available evidence was very low for drawing any conclusions about the effectiveness of glass ionomer cement (GIC) sealant or the relative effectiveness of different types of sealants. Nevertheless, the American Academy of Pediatric Dentistry ${ }^{3}$ recommends using pit and fissure sealants to prevent and arrest non-cavitated carious lesions (active white spot lesion) on occlusal surfaces of permanent and deciduous molars in caries risk children and adolescents.

High-viscosity GIC, used in ART, was developed as an alternative to the classic approach on restoring and sealing surrounding pit and fissures on deciduous or permanent teeth. The sealant technique is easy to perform and does not require electric equipment (electrical mixers or light curing devices), ${ }^{1}$ and it is not as technique sensitive to humidity as a resin-based sealant or a resin reinforced GIC sealant. ${ }^{1,3,4}$ Nowadays, resin-based pit and fissures sealant are the first option of dental material for this purpose. GIC sealants are yet to have longterm retention as resin-based ones. However, glass ionomer cement's adhesion to the tooth structure is less technique sensitive than the resin-based materials. For that matter, they can be used in humid conditions ${ }^{3,4}$ as in apprehensive and/or pre cooperative children's dental care.5,6

Conventional GIC are composed of vitreous dust particles and fluid polyalkenoates acids. The second generation of conventional GIC is known as high viscous, they were developed to improve some of their physical properties. This material presents optimized concentration and molecular weight of the polyacid and a better distribution of smaller glass particle size, leading to a high power:liquid ratio than the first generation of conventional GIC. ${ }^{7}$ When the two components of a GIC material are mixed, they set an acid/base reaction that results in salt and water. The initial setting usually occurs during the first 5 minutes, and complete maturation of GIC can take up to one year.

Since GIC are prone to absorb and lose water, their surface must be protected with petroleum jelly or varnish. ${ }^{1}$ Loosely bound water of a newly placed GIC can be altered by dehydration or saliva. However, loosely bound water is also responsible for positive characteristics such as reduced polymerization shrinkage, continuing chemistry throughout the bulk material and fluoride release. ${ }^{4}$ Loosely bound water can be defined as the fraction removed by dissection and the tightly bound fraction is structurally related to the GIC. Strongly bound water is located within the structure of the GIC, which is the largest fraction of water in this cement. ${ }^{8}$ Fluoride release may vary between different brands of conventional GIC due to their power:liquid ratio, especially under acidic conditions. These authors found a positive linear correlation between fluoride release and higher acid erosion. ${ }^{9}$

Apart from fluoride release, GIC can also incorporate it again ${ }^{1,10}$ from other fluoridated products as in dentifrices and/or gels. Therefore, GIC restorations and sealants act as a reservoir of fluoride. That is why some authors ${ }^{1,6}$ have recommended their use in pedodontics for the combined properties of chemical adhesion to tooth structure, liberation of fluoride and the child's ability to cooperate.

Since water lixiviates fluoride to dental enamel and this would aid non-cavitated carious lesions, this study aimed to evaluate the presence, or not, of in vitro surface dye penetration of two conventional GIC being one of them a high viscous ionomer used as pit and fissure sealants. 


\section{MATERIALS AND METHODS}

This study was conducted with a high viscous GIC on Group 1 (Ketac ${ }^{\mathrm{TM}}$ Molar EasyMix, 3M, ESPE, Saint Paul, Minnesota, USA) as a control group and a first generation conventional GIC on Group 2 (Meron, Voco, Cuxhaven, Cuxhaven, Germany). This high viscous GIC has been tested since $1997^{5}$ on its old formulation and it is recommended for the ART technique. ${ }^{1}$ The test group involved a conventional $\mathrm{GIC}^{11}$ from the first generation of glass-ionomers. Twenty specimens were made from each GIC group using a stainless-steel matrix with a $4 \mathrm{~mm}$ diameter and a $2 \mathrm{~mm}$ height. ${ }^{12}$ This matrix was previously isolated with solid petroleum jelly (Hemafarma Comércio e Indústria Farmacêutica Ltda., São Gonçalo, Rio de Janeiro, Brazil) using a small brush (Benda Brush DFL - Indústria e Comércio S.A., Rio de Janeiro, Rio de Janeiro, Brazil). The matrix was placed on top of an extrafine polyester strip (Super Dentária Napoleão Ltda., Rio de Janeiro, Rio de Janeiro, Brazil) that remained over a glass plate. These materials were dosed and manipulated in accordance with their manufacturer's recommendations. They were both agglutinated with a flexible nylon spatula (No 142 J.O.N. Comércio De Produtos Ltda., São Paulo, São Paulo, Brazil) on a proper pad of paper. Mixing time for both GIC groups was performed based on the manufacturer's specification. These materials were inserted into the matrix employing the same plastic spatula. Petroleum jelly was applied over with a gloved forefinger, and a 10 second digital pressure was exerted on the specimens after the initial loss of the material's gloss. ${ }^{1}$

After the materials' setting time, all samples were embedded in wax (Cerafix - Manufat. e Com. de Ceras p/ Moldes Ltda., Pradópolis, São Paulo, Brazil). In total, four wax blocks were used to embed 10 samples from each GIC group. Only the surface area that received digital pressure with petroleum jelly was exposed to $\mathrm{pH}$ cycling process. Embedded samples from each group were placed in two sealed plastic vials containing $1,600 \mathrm{ml}$ of remineralizing solution for 18 hours. This solution contained: $1.5 \mathrm{mM}$ calcium; $0.9 \mathrm{mM}$ phosphate; $150 \mathrm{mM}$ potassium chloride; $0.05 \mathrm{ppm} F$ in $20 \mathrm{mM}$ TRIS (tris-hydroxymethyl aminomethane) buffer at $\mathrm{pH} 7 \cdot 4 \cdot{ }^{13}$ The samples remained in a kiln (Mod. 001/1 - Fanem ${ }^{\circledR}$ Ltda., São Paulo, São Paulo, Brazil) at $37^{\circ} \mathrm{C}$ for 18 hours. After that, the specimens were washed in running water for 10 seconds and left to dry on top of an absorbent paper (Softy's - Melhoramentos Papéis Ltda., Caieiras, São Paulo, Brazil) at room temperature. To simulate a high cariogenic challenge, the samples were placed on two different plastic vials with lids containing $3,200 \mathrm{ml}$ of a demineralizing solution for 6 hours. This demineralizing solution contained: 2.0 mM calcium; 2.0 mM phosphate; $0.03 \mathrm{ppmF}$ in $75 \mathrm{mM}$ acetate buffer at $\mathrm{pH} 4 \cdot 3 \cdot{ }^{12}$ The specimens were washed in running water for 10 seconds and brushed with an extra-soft bristles infant toothbrush (Colgate-Palmolive ${ }^{\circledR}$ - Indústria e Comércio Ltda., São Bernardo do Campo, São Paulo, Brazil). Following, $0.1 \mathrm{ml}$ of a sodium fluoride dentifrice containing 1,450 ppm F (Colgate-Palmolive ${ }^{\circledR}$ - Indústria e Comércio Ltda., São Bernardo do Campo, São Paulo, Brazil) was used to brush 10 embedded samples at a time. Brushing was performed by a single operator with back and forward movements for 10 seconds. The specimens were again washed in running water for 10 seconds and left to dry as previously described.

The $\mathrm{pH}$ cycling process along with the toothbrushing procedure was performed for 5 days. The embedded samples remained in two different closed plastic vials on the weekend with the remineralizing solution in a kiln $\left(37^{\circ} \mathrm{C}\right) .{ }^{13}$

After the end of the $\mathrm{pH}$ cycle, the embedded samples were washed in running water for 10 seconds, dried as described, and immersed in an aqueous solution of $1 \%$ methylene blue for 2 hours. ${ }^{5}$ This part of the experiment was performed on a sealed plastic container at room temperature. Again, embedded 
samples were washed with water (10 s) and left to dry at room temperature. All samples were removed from the embedding wax and surface dye penetration was accessed individually. Each sample was sectioned with a refrigerated diamond disc (Horico, Superdiaflex Diamond H355 F 220, South Plainfield, New Jersey, USA) on a low speed handpiece. Although most halves had the approximately same measurement only the most dyed one was considered for analysis. The interrated reliability was substantial (Kappa o,8). Two independent examiners evaluated all samples with the aid of a dental caliper ( $\mathrm{N}^{\mathrm{O}} 3805-100$, Masel, Bristol, Tennessee, USA).

Superficial dye penetration was scored from o to 4 according to Table 1 . The Mann-Whitney Rank Sum test was used to evaluate statistical differences between GIC groups; statistical significance was set to $5 \%(\mathrm{p}=0.05)$.

Table 1 | Scores of superficial dye penetration

\begin{tabular}{|l|l} 
Score 0 & Without Surface staining \\
\hline Score 1 & Staining depth: $0.1 \mathrm{~mm}$ to $0.5 \mathrm{~mm}$ \\
\hline Score 2 & Staining depth: $0.6 \mathrm{~mm}$ to $1.0 \mathrm{~mm}$ \\
\hline Score 3 & Staining depth: $1.1 \mathrm{~mm}$ to $1.5 \mathrm{~mm}$ \\
\hline Score 4 & More than $1.5 \mathrm{~mm}$ of staining depth \\
\hline
\end{tabular}

\section{RESULTS}

After the third day of $\mathrm{pH}$ cycling, all samples from the conventional GIC (Group 2) had a more whitish surface suggesting an erosion process. The high viscous GIC (Group 1) remained with the same surface color during the whole experiment duration.

All 40 specimens showed scores 2, 3 or 4 . Table 2 shows scores and percentages of surface dye penetration on both tested GIC treated with Methylene Blue. On Group 1 (high viscous GIC), scores 2 and 3 were observed with the same frequency (9 samples each, 45\%). On Group 2 (conventional GIC), score 2 was found in 9 samples (45\%), score 3 was found in 8 samples (40\%), and score 4 in 3 samples (15\%).
Table 2 | Scores and percentages of surface dye penetration on Group 1 (high viscous GIC) and Group 2 (conventional GIC) treated with Methylene Blue

\begin{tabular}{c|c|c|c|c}
\hline Scores & Group 1 (high viscous GIC) & \multicolumn{2}{|c}{} & Group 2 (conventional GIC) \\
\hline & Frequency & Percentage & Frequency & Percentage \\
\hline 0 & 0 & 0 & 0 & 0 \\
\hline 1 & 0 & 0 & 0 & 0 \\
\hline 2 & 9 & $45 \%$ & 9 & $45 \%$ \\
\hline 3 & 9 & $45 \%$ & 8 & $40 \%$ \\
\hline 4 & 2 & $10 \%$ & 3 & $15 \%$ \\
\hline Total & 20 & $100 \%$ & 20 & $100 \%$ \\
\hline
\end{tabular}

${ }^{a}$ No statistical difference according to Mann-Whitney's test $(p=0.883)$. GIC: Glass lonomer Cement.

\section{DISCUSSION}

GIC sealant can be used to seal pits and fissures, preventing or arresting enamel caries. Sealant should not be placed over a dark colored pit and fissure since this sign is usually related to an arrested carious lesion or it could be due to a superficial stain. ${ }^{1}$ According to the ART technique, ${ }^{1,5}$ the recommended ionomer cement to seal pit and fissures are the high viscous GIC that tend to be more expensive than conventional ones. Dentists and/or their purchasing department sometimes choose a dental material through the manufacturer's recommendation and/ or by a budget, even though a GIC is recognizably a conventional one and not a high viscous ionomer. High viscous GIC must be utilized for a successful application of the ART technique.

In this study, the specimens' thickness was $2 \mathrm{~mm}$, based on Souchois and Vieira. ${ }^{14}$ When these authors applied a high viscous GIC (Group 1) as a fissure sealant using the ART technique on extracted teeth, they found $2 \mathrm{~mm}$ as the average thickness from the base of the fissure to the surface of the material. Thus, a metal matrix with five orifices measuring $4 \mathrm{~mm}$ in diameter and $2 \mathrm{~mm}$ in height was used. Another research ${ }^{12}$ used a similar matrix with the same measurements. They evaluated the effectiveness of different types of surface protectors applied to three different dental materials: a high 
viscous GIC, a GIC modified by a composite resin and a composite resin modified by polyacids. All specimens were exposed to a dye for 24 hours. However, they did not simulate oral conditions by applying demineralization and remineralization $(\mathrm{pH}$ cycling) or brushing the samples.

Petroleum jelly was placed over a gloved forefinger to promote dental pressure over both GIC, as described by the ART technique.,5 The finger pressure technique has demonstrated a satisfactory penetration of different GIC sealants into enamel pit and fissure. Moreover, minimal material void and both minimal marginal and surface dye penetration were observed in surfaceprotected sealed extracted teeth. ${ }^{5}$ GIC is sensitive to dehydration at any time of the reaction and/or the setting process. One must take into consideration that GIC requires several months to become stable. ${ }^{1}$

It is important to study surface dye penetration of GIC because of fluoride elution. All specimens from both GIC tested groups had surface dye penetration scores from 2 to 4 (from $0.6 \mathrm{~mm}$ to more than 1.5 $\mathrm{mm})$. Under the naked eye, a more whitish surface was observed on Group 2 (first generation of conventional GIC) samples after the $\mathrm{pH}$ cycling process. The mechanism of GIC dissolution was explained by Kuhn and Wilson ${ }^{15}$ and Fukusawa et al. ${ }^{16}$ as incongruent and that most of the leached chemicals derive from the matrix and the partially reacted glass particles. The release of these elements occurs from three mechanisms: surface wash-off, diffusion through the bulk of the cement, or from pores and cracks on its surface. This means that fluoride release can occur from the whole body of the specimen and not just from the surface, as implied in calculations using mass per unit area. Momoi and $\mathrm{McCabe}^{17}$ demonstrated that the early fluoride release rate is a function of specimen area, and the long-term value is more likely to be a function of volume. Sodium and fluoride ions are the primary chemical components eluted from an ASPA cement, and elution occurred due to a diffusion process. ${ }^{8}$ To preserve electroneutrality, equal amounts of fluoride and sodium were eluted from GIC samples in distilled water. Sodium is the only cation eluted in major amounts. ${ }^{18}$

Clinically, fluoride elution is desirable because of its cariostatic effect. An in vitro study by Serra and Cury ${ }^{19}$ verified that GIC restorations interfered with the formation and progression of caries-like lesions in enamel when compared to composite resin. According to Tantbirojn et al., ${ }^{20}$ the change in mineral content in bovine enamel, sponsored by the resin-modified GIC, was more pronounced up to $1.0 \mathrm{~mm}$ from its edge. This suggests that inhibition of the demineralization effect can be seen near this type of ionomer cement ( $<1.0 \mathrm{~mm}$ ). Inhibition effects were observed up to $7.0 \mathrm{~mm}$ of distance from the resin-modified GIC restoration. These two in vitro studies $^{19,20}$ indicated that GIC would be particularly interesting to use in high caries risk individuals.

Although $95 \%$ of a GIC sealant were clinically scored as totally lost after 36 months, Mejáre and Mjör ${ }^{21}$ detected some remnants of this material in 84\% of the replicas from these teeth. Even so, no caries was recorded in those teeth sealed with a GIC after its loss. According to Wilson et al., ${ }^{22}$ polyacrylate ions become irreversibly attached to the surface of hydroxypatite by displacing existing phosphate ions. For that matter, a distinct zone of interaction between the GIC and both enamel or dentin, called GIC-tooth interaction interphase, was observed by Ngo et al. ${ }^{23}$ This zone of 1 to $2 \mu \mathrm{m}$ wide contributes to the adhesion and high resistance to microleakage of GIC restorations. Ten Cate et al. ${ }^{24}$ detected a hypermineralization area of dentin close to or in contact with GIC restorations and a lower susceptibility of caries on dentin cavity walls after three months in situ. A systematic review from $2020^{25}$ also confirms these findings occurring in both enamel and/or dentin, being described as an acidic resistant layer formed within 1 to 10 days of contact between the GIC and the tooth surface. In the present study, most samples from both GIC tested resulted in a superficial dye penetration of 0.6 to 1.5 
$\mathrm{mm}$ depth. It is well known ${ }^{26}$ that the caries process on occlusal surfaces does not start at the bottom of a pit and/or a fissure but at their entrance. Carvalho et al. ${ }^{27}$ demonstrated that favorable conditions for plaque accumulation such as tooth specific anatomy, the stage of tooth eruption and its functional usage against their occluding opposing tooth are important factors to be considered when analyzing caries risk factors. Adequate access for tooth brushing is also relevant. ${ }^{27}$ In the thinner portions of the GIC sealant, located at the pit and/or fissure's entrance, surface dye penetration of that depth could be adequate to promote fluoride lixiviation from the GIC. This lixiviation of fluoride could be beneficial not only to the external enamel surface alongside the GIC sealant but also to the inner part of the enamel that touches it. This feature could improve fluoride gain to an active white spot lesion sealed underneath a high viscous GIC. The present study was based on previous ones regarding fluoride elution..$^{8-9,17-20}$ For that matter, the authors did not perform this measurement utilizing a fluoride-ion electrode. This limitation may be assessed in future investigations. Further clinical studies would also have to be done to elucidate the importance of water penetration for fluoride lixiviation from GIC.

Based on the findings of this study, both conventional and high viscous GIC tested had surface dye penetration at similar levels, from 0.6 to $1.5 \mathrm{~mm}$, with no statistical difference among them. This could be of interest whenever there is an active white spot lesion at the inner cusp walls since it could probably beneficiate by fluoride lixiviation.

\section{REFERENCES}

1. Frencken JE, Holmgren CJ. Atraumatic Restorative Treatment (ART) for dental caries. Nijmegen: STI Book; 1999.

2. Ahovuo-Saloranta A, Forss H, Walsh T, Nordblad A, Mäkelä M, Worthington HV. Pit and fissure sealants for preventing dental decay in permanent teeth. Cochrane Database Syst Rev. 2017;31(7):CDo01830. https://doi.org/10.1002/14651858. CDo01830.pub5.
3. American Academy of Pediatric Dentistry. The reference Manual of Pediatric Dentistry [Internet]. Chicago: American Academy of Pediatric Dentistry; 2016 [cited 2019 Oct 2019]. Available from: https://www.aapd.org/research/oral-healthpolicies--recommendations/pit_and_fissure_sealants/

4. Davidson AL. Advances in Glass-Ionomer Cements. J Appl Oral Sci. 2006;14(Suppl):3-9. https://doi.org/10.1590/s167877572006000700002

5. Smales RJ, Gao W, Ho FT. In vitro evaluation of sealing pits and fissures with newer glass-ionomer cements developed for the ART technique. J Clin Pediatr Dent. 1997;21(4):321-3.

6. Berg JH, Croll TP. Glass ionomer restorative cement systems: an update. Pediatr Dent. 2015;37(2):116-24.

7. Guggenberg R, May R, Stefan KP. New trends in glass-ionomer chemistry. Biomaterials. 1998;19(6):479-83. https://doi. org/10.1016/s0142-9612(97)00127-0

8. Crisp S, Lewis BG, Wilson AD. Glass ionomer cements: Chemistry of erosion. J Dent Res. 1976;55(6):1032-41. https://doi. org/10.1177/00220345760550060501

9. Bueno LS, Silva RM, Magalhães APR, Navarro MFL, Pascotto RC, Buzalaf MAR, et al. Positive correlation between fluoride release and acid erosion of restorative glass-ionomer cements. Dent Mater. 2019;35(1):135-43. https://doi. org/10.1016/j.dental.2018.11.007.

10. Forss H, Seppä L. Studies on the effect of fluoride release by glass ionomers in the oral cavity. Adv Dent Res. 1995;9(4): 389-93. https://doi.org/ 10.1177/o8959374950090040801

11. Perez CR, Jr Hirata R, Silva AHMFT. Glaze/composite sealant on the $3-\mathrm{D}$ surface roughness of esthetic materials. Oper Dent. 2009;34(6):674-80. https://doi.org/10.2341/o8-014-L

12. KaraoĞlanoĞlu S, Akgül N, Özdabak HN, Akgül HM. Effectiveness of surface protection for glass-ionomer, resinmodified glass-ionomer and polyacid-modified composite resins. Dent Mater J. 2009;28(1):96-101.

13. Argenta RM, Tabchoury CP, Cury JA. A modified pH-cycling model to evaluate fluoride effect on enamel demineralization. Pesqui Odontol Bras. 2003;17(3):241-6. https://doi. org/10.1590/s1517-74912003000300008

14. Souchois MW, Vieira RS. Effect of a glass ionomer cement and a fluoride varnish on cross-sectional microhardness values of artificial occlusal caries: In vitro study. Ind J Dent Res. 2012;23(6):732-7. https://doi.org/10.4103/0970-9290.111248

15. Kuhn AT, Wilson AD. The dissolution mechanisms of silicate and glass-ionomer dental cements. Biomaterials. 1985;6(6):378-82. https://doi.org/10.1016/0142-9612(85)90096-1 
16. Fukasawa M, Matsuya S, Yamane M. Mechanism for erosion of glass-ionomer cements in an acidic buffer solution. J Dent Res. 1987;66(12):1770-4. https://doi.org/10.1177/002203458 70660121401

17. Momoi Y, MC Cabe JF. Fluoride release from light-activated glass ionomer restorative cements. Dent Mater. 1993;9(3):151-4. https://doi.org/10.1016/0109-5641(93)90112-4

18. Wilson AD, Groffman DM, Kuhn AT. The release of fluoride and other chemical species from a glass-ionomer cement. Biomaterials. 1985;6(6):431-3. https://doi.org/10.1016/01429612(85)90107-3

19. Serra MC, Cury JA. The in vitro effect of glass-ionomer cement restoration on enamel subjected to a demineralization and remineralization model. Quintessence Int. 1992;23(2):143-7.

20. Tantbironjn D, Douglas WH, Versluis A. Inhibitive Effect of a Resin-Modified Glass Ionomer Cement on Remote Enamel Artificial Caries. Caries Res. 1997;31(4):275-8o. https://doi. org/10.1159/ooo262411

21. Mejàre I, Mjör IA. Glass ionomer and resin-based fissure sealants: a clinical study. Scand J Dent Res. 1990;98(4):345-50. https://doi.org/10.1111/j.16oo-0722.1990.tboo983.x
22. Wilson AD, Prosser HJ, Powis DM. Mechanism of adhesion of polyelectrolyte cements to hydroxyapatite. J Dent Res. 1983;62(5): 590-2. https://doi.org/10.1177/00220345830620051801

23. Ngo H, Mount GJ, Peters MC. A study of glass-ionomer cement and its interface with enamel and dentin using a lowtemperature, high-resolution scanning electron microscopic technique. Quintessence Int. 1997;28(1): 63-9.

24. Ten Cate JM, Buijs MJ, Damen JJM. The effects of GIC restorations on enamel and dentin demineralization and remineralization. Adv Dent Res. 1995;9(4):384-8. https:// doi.org/10.1177/08959374950090040701

25. Mustafa HA, Soares AP, Paris S, Elhennawy K, Zaslansky P. The forgotten merits of GIC restorations: a systematic review. Clin Oral Investig. 2020;24(7):2189-201. https://doi. org/10.1007/s00784-020-03334-o

26. Hicks MJ, Flaitz CM. Caries-like lesion formation in oclusal fissures: an in vitro study. Quintessence Int. 1986;17(7):405-10.

27. Carvalho JC, Ekstrand KR, Thylstrup A. Dental plaque and caries on occlusal surfaces of first permanent molars in relation to stage of eruption. J Dent Res. 1989;68(5):773-9. https://doi.org/10.1177/00220345890680050401 